\title{
Peran Keluarga Dalam Menurunkan Tanda Gejala Halusinasi Pasien Skizofrenia: Literature Review
}

\author{
Nevita Candra Pangestika ${ }^{1}$,Eka Budiarto ${ }^{2 *}$ \\ 1,2 Program Studi Sarjana Keperawatan, Universitas Muhammadiyah Pekajangan Pekalongan, \\ Indonesia \\ *email: ekabudiarto4321@gmail.com
}

\begin{abstract}
Schizophrenia is a mental illness that has a long-term impact. One of the symptoms of schizophrenia is hallucinations. Hallucinations are perceptual disturbances in which the client perceives something that does not exist. One of the things that families do is help family members by playing a role in assisting the clients in controlling hallucinations. The study aimed to determine the role of the family in reducing the hallucination symptoms of schizophrenic patients based on the available evidence. The literature review used Scopus, Science Direct, and GARUDA databases. Articles are selected based on the suitability of keywords, topics, as well as inclusion and exclusion criteria. The appraisal instrument by Hawker was used to select highquality evidence. The findings of this study highlighted three levels of family roles in reducing symptoms of hallucinations in schizophrenic patients. The first level, the family must be able to see the patient's needs and maintain parental closeness. The second level, the family must be able to provide financial support for patient care, the family should be involved in groups that provide support as well. The third levels, all families must develop a good relationship to help patients with hallucinations to change their attitudes and behavior. Family roles are essential in reducing symptoms of hallucination in schizophrenic patients. This evidence can be used as scientific references to be applied as nursing care interventions.
\end{abstract}

Keywords: Family Roles, Hallucinations, Schizophrenia

\begin{abstract}
Abstrak
Skizofrenia merupakan penyakit kejiwaan yang memiliki dampak jangka panjang. Salah satu tanda gejala skizofrenia adalah halusinasi. Halusinasi ialah gangguan persepsi di mana klien mempersepsikan sesuatu yang sebenarnya tidak terjadi. Salah satu yang di lakukan keluarga ialah membantu anggota keluarganya dengan cara ikut berperan membantu klien untuk bisa mengontrol halusinasi. Penelitian ini bertujuan untuk mengetahui peran keluarga dalam menurunkan tanda gejala halusinasi pasien skizofrenia berdasarkan literatur evidence yang tersedia. Penelitian menggunakan metode literature review. Database yang digunakan untuk pencarian artikel adalah Scopus, Science Direct, dan GARUDA. Artikel diseleksi berdasarkan kesesuaian dengan kata kunci, topik serta kriteria inklusi dan eksklusi yang telah ditentukan. Hasil penelusuran didapatkan sebanyak 5 artikel, 2 artikel berbahasa Inggris dan 3 artikel berbahasa Indonesia. Instrumen telaah kritis yang digunakan untuk menelaah kualitas artikel adalah instrumen oleh Hawker et al 2002. Terdapat temuan berupa 3 tingkatan peran keluarga dalam menurunkan tanda gejala halusinasi pasien skizofrenia : tingkatan pertama keluarga harus mampu melihat kebutuhan pasien dan mempertahankan kedekatan orangtua, Tingkatan kedua keluarga harus mampu memberikan dukungan financial untuk perawatan pasien dan terlibatan dalam kelompok yang member dukungan dan Tingkatan ketiga keluarga harus mengembangkan hubungan dengan benar untuk membantu pasien halusinasi untuk merubah sikap dan perilaku. Upaya peningkatan peran keluarga dalam menurunkan tanda gejala halusinasi pasien skizofrenia ini didapatkan dari bukti ilmiah yang valid sehingga dapat dijadikan referensi ilmiah untuk diaplikasikan sebagai intervensi asuhan keperawatan.
\end{abstract}

Kata Kunci : Halusinasi, Peran Keluarga, Skizofrenia. 


\section{Prosiding Seminar Nasional Kesehatan Lembaga Penelitian dan Pengabdian Masyarakat Universitas Muhammadiyah Pekajangan Pekalongan

\section{Pendahuluan}

Gangguan jiwa merupakan suatu perubahan yang menyebabkan adanya gangguan pada jiwanya, yang menyebabkan penderitaan pada individu atau adanya hambatan dalam melakukan aktifitas (Keliat, dkk, 2013).

Sebagaian besar gangguan jiwa ialah penderita skizofrenia. Masalah gangguan jiwa memang sudah menjadi masalah yang serius diseluruh dunia. Diperkirakan ada sekitar 450 juta orang didunia yang mengalami gangguan kesehatan jiwa. Sementara itu diwilayah Asia Tenggara, hampir satu pertiga dari produk diwilayah ini pernah mengalami gangguan jiwa (WHO,2017).

Skizofrenia sebagai penyakit neorologis yang mempengaruhi persepsi klien, cara berpikir, bahasa, emosi, dan prilaku sosialnya (Yosep, 2014). Skizofrenia biasanya ditandai dengan gejala positif seperti halusinasi dan waham, gejala negatif biasanya seperti kurangnya berbicara dan kurangnya motivasi. Salah satu tanda skizofrenia adalah halusinasi.

Salah satu yang bisa dilakukan oleh keluarga dalam membantu anggota keluarga yang mengalami halusinasi adalah dengan cara ikut berperan membantu klien untuk bisa mengontrol halusinasi, dan hal ini yang membuat keluarga juga perlu untuk mengetahui dan memahami dengan benar strategi pelaksanaan (SP) halusinasi, dan untuk bisa membantu meningkatkan peran keluarga, peran perawat juga diperlukan yaitu memberikan health education atau intervensi strategi pelaksanaan keluarga yang benar yang bisa dilakukan oleh keluarga di rumah (Safino, 2014).

Keluarga sangat berperan dalam kesembuhan pasien dalam asuhan yang diperlukan di rumah. Keberhasilan perawat di rumah sakit dapat sia-sia jika tidak diteruskan dirumah karena mengakibatkan pasien kambuh (Wardaningsih, 2010). Peran keluargalah dibutuhkan sejak awal asuhan keperawatan dirumah sakit untuk meningkatkan kemampuan keluarga merawat pasien dirumah sehingga dapat mencegah (Nasir \& Muhith, 2011).

Berdasarkan uraian tersebut maka ingin mengetahui bagaimana peran keluarga dalam menurunkan tanda gejala halusinasi pasien skizofrenia sangatlah dibutuhkan.

\section{Literatur Review (jika ada)}

Literature review berisi diskusi pengetahuan tentang topik yang sedang dipelajari untuk memperkuat gagasan riset.

\section{Metode}

Dalam penelitian ini menggunakan literature review yaitu melakukan proses pencarian mendalam mengenai informasi terpublikasi sesuai topik. Proses pencarian artikel menggunakan Scopus, Science Direct, dan GARUDA. Sebagai alternative pencarian Scopus dengan kata kunci : "Hallucination" AND "Family" AND "Role" dengan hasil 209, kemudian dilakukan identifikasi artikel terdapat Artikel di identifikasi melalui judul dengan baca cepat 78, 1 artikel yang masuk dalam kriteria inklusi. Pencarian melalui ScienceDirect dengan kata kunci : "Hallucination" AND "Schizophrenia" AND "Sign symptom" AND "Family role" Jumlah artikel dengan kata kunci tersebut 4.307, kemudian dilakukan identifikasi artikel terdapat Artikel di identifikasi melalui judul dengan baca cepat 578, 1 artikel yang masuk dalam kriteria inklusi. Menggunakan 


\section{Prosiding Seminar Nasional Kesehatan Lembaga Penelitian dan Pengabdian Masyarakat Universitas Muhammadiyah Pekajangan Pekalongan}

Garuda kata kunci : "Hallucination" AND "Schizophrenia" Jumlah artikel dengan kata kunci tersebut 36, kemudian dilakukan identifikasi artikel terdapat Artikel di identifikasi melalui judul dengan baca cepat 13, 3 artikel yang masuk dalam kriteria inklusi. Sehingga artikel yang termasuk dalam kategori kriteria inklusi adalah 5 artikel.

\section{Hasil dan Pembahasan}

\section{Hasil}

Berikut merupakan tabel peran keluarga dalam menurunkan tanda gejala halusinasi pasien skizofrenia yang dapat di uraikan sebagai berikut :

Tabel 4.1 Identifikasi Peran Keluarga Dalam Menurunkan Tanda Gejala Halusinasi Pasien Skizofrenia

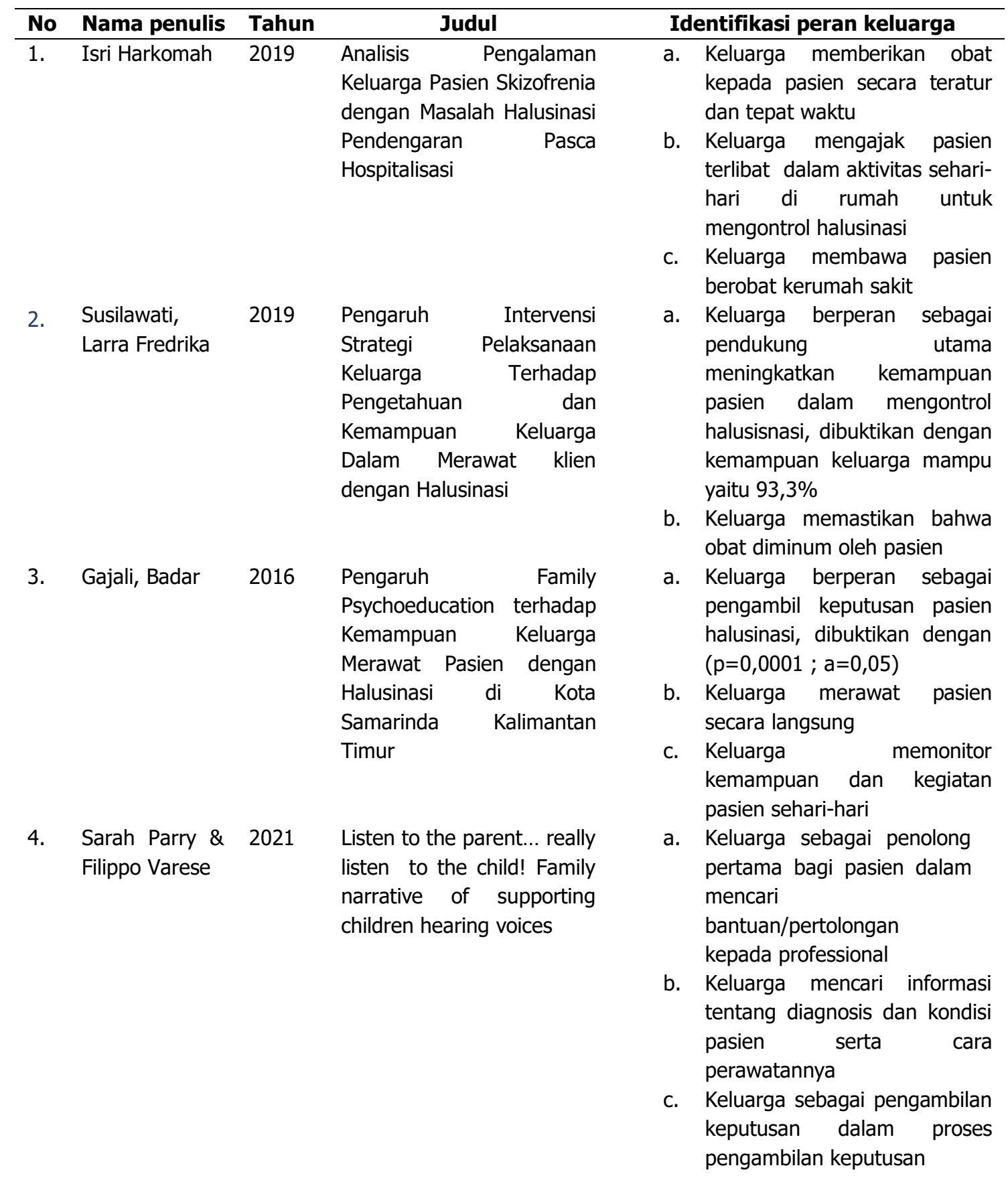




\section{Prosiding Seminar Nasional Kesehatan Lembaga Penelitian dan Pengabdian Masyarakat Universitas Muhammadiyah Pekajangan Pekalongan}

\begin{tabular}{|c|c|c|c|c|}
\hline No & Nama penulis & Tahun & Judul & Identifikasi peran keluarga \\
\hline 5. & $\begin{array}{l}\text { Elisabet Agnes } \\
\text { Jaftoran, Budi } \\
\text { Anna Keliat, } \\
\text { EsYuliaWardani }\end{array}$ & 2020 & $\begin{array}{l}\text { Nursing intervention, } \\
\text { family's role, cadre's role } \\
\text { and medical services: Case } \\
\text { series on client with } \\
\text { hallucination and self-care } \\
\text { deficit }\end{array}$ & $\begin{array}{l}\text { a. Keluarga sebagai pemberi } \\
\text { perawatan khususnya kepada } \\
\text { pasien }\end{array}$ \\
\hline
\end{tabular}

Berdasarkan penjabaran dari tabel tersebut, dapat disimpulkan bahwa peran keluarga dalam menurunkan tanda gejala halusinasi pasien skizofrenia di antaranya : keluarga memberikan obat kepada pasien secara teratur dan tepat waktu, keluarga mengajak pasien terlibat dalam aktivitas sehari-hari di rumah untuk mengontrol halusinasi, keluarga membawa pasien berobat kerumah sakit, keluarga berperan aktif sebagai pendukung utama meningkatkan kemampuan pasien dalam mengontrol halusinasi, keluarga memastikan bahwa obat diminum oleh pasien, keluarga berperan sebagai pengambil keputusan pasien halusinasi, keluarga merawat pasien secara langsung, keluarga memonitor kemampuan dan kegiatan pasien sehari-hari, keluarga sebagai penolong pertama bagi pasien dalam mencari bantuan/pertolongan kepada professional, keluarga mencari informasi tentang diagnosis dan kondisi pasien serta cara perawatannya, keluarga sebagai pengambilan keputusan dalam proses pengambilan keputusan, Keluarga sebagai pemberi perawatan khususnya kepada pasien.

Gambar 4.2 Peran Keluarga Dalam Menurunkan Tanda Gejala Halusinasi Pasien

Skizofrenia Berdasarkan Hasil Literature Review

\section{Tingkatan peran Peran keluarga dalam menurunkan halusinasi keluarg}

\begin{tabular}{ll}
\hline Tingkatan 1 & Peran keluarga tingkatan pertama yaitu keluarga memberikan obat dan \\
& memastikan obat diminum oleh pasien secara teratur dan tepat waktu, keluarga \\
& membawa pasien berobat kerumah sakit, keluarga berperan sebagai pengambil \\
& keputusan pasien halusinasi, keluarga merawat pasien secara langsung, keluarga \\
& mencari informasi tentang diagnosis dan kondisi pasien serta cara perawatannya, \\
& keluarga sebagai pengambil keputusan dalam proses pengambilan keputusan, \\
& keluarga sebagai pemberi perawatan khususnya kepada pasien
\end{tabular}

Tingkatan 2 Peran keluarga tingkatan kedua yaitu keluarga membawa pasien berobat kerumah sakit dan keluarga sebagai penolong pertama bagi pasien dalam mencari bantuan/pertolongan kepada professional

Tingkatan 3 Peran keluarga tingkatan ketiga yaitu keluarga mengajak pasien terlibat dalam aktivitas sehari-hari di rumah untuk mengontrol hallusinasi, keluarga berperan sebagai pendukung utama meningkatkan kemampuan pasien dalam mengontrol hallusinasi, dan keluarga memonitor kemampuan dan kegiatan pasien sehari-hari.

Berdasarkan literature review pada 5 artikel diperoleh peran keluarga dalam merawat pasien halusinasi meliputi 3 tingkatan yaitu tingkatan pertama meliputi keluargamemberikanobat dan memastikan obat diminum oleh pasien secara teratur dan tepat waktu, keluarga membawa pasien berobat kerumah sakit, keluarga berperan sebagai pengambil keputusan pasien halusinasi, keluarga merawat pasien secara 


\section{Prosiding Seminar Nasional Kesehatan Lembaga Penelitian dan Pengabdian Masyarakat Universitas Muhammadiyah Pekajangan Pekalongan}

langsung, keluarga mencari informasi tentang diagnosis dan kondisi pasien serta cara perawatannya, keluarga sebagai pengambil keputusan dalam proses pengambilan keputusan, keluarga sebagai pemberi perawatan khususnya kepada pasien. Tingkatan kedua meliputi keluarga membawa pasien berobat kerumah sakit dan keluarga sebagai penolong pertama bagi pasien dalam mencari bantuan/pertolongan kepada professional. Tingkatan ketiga meliputi keluarga mengajak pasien terlibat dalam aktivitas sehari-hari di rumah untuk mengontrol halusinasi, keluarga berperan sebagai pendukung utama meningkatkan kemampuan pasien dalam mengontrol halusinasi dan keluarga memonitor kemampuan dan kegiatan pasien sehari-hari.

\section{Pembahasan}

Hasil dari literatur review ini setelah melakukan analisa dari 5 artikel penelitian merangkum keseluruhan hasilnya menjadi beberapa yang memiliki kesamaan konsep. Penelitian menunjukan bahwa terdapat 3 tingkatan peran keluarga.

Tingkatan pertama adalah keluarga memberikan obat dan memastikan obat diminum oleh pasien secara teratur dan tepat waktu. Terdapat 2 artikel yang meneliti keluarga memberikan obat dan memastikan obat diminum oleh pasien secara teratur yaitu artike Isti Harkomah (2019) dan Susilawati, Larra Fredrika (2019). Secara garis besar kedua artikel menggambarkan bahwa pengalam keluarga dalam merawat pasien halusinasi meliputi bagaimana keluarga dalam merawat seperti memberikan obat dan memberikan kegiatan untuk pasien, upaya keluarga dalam merawat seperti memberi obat dan membawa pasien kerumah sakit jika pasien kambuh. Merawat pasien berarti juga harus terlibat langsung dalam program pengobatan pasien, peran keluarga dibutuhkan dalam mengawasi pasien minum obat. Oleh Karena itu, penting bagi keluarga untuk mengetahui tentang obat dan efek samping obat. Keluarga diharapkan mengetahui manfaat obat, jenis, dosis, waktu, cara pemberian dan efek samping obat (Videbeck, 2008).

Dukungan keluarga selama pasien dirawat di rumah sakit sangat dibutuhkan sehingga pasien termotivasi untuk sembuh. Demikian juga saat pasien tidak lagi dirawat di rumah sakit (dirawat di rumah). Keluarga yang mendukung pasien secara konsisten akan membuat pasien mampu mempertahankan program pengobatan secara optimal (Keliat, 2014).

Keterlibatan keluarga dalam pengambilan keputusan keperawatan pasien meningkatkan hasil dengan cara pendidikan dan dukungan keluarga untuk bekerja sama (Stuart \& Laraia, 2005). Keluarga yang mengetahui betul kondisi pasien akan memberikan serta menyediakan perawatan kepada pasien secara berskala. Penyediaan pelayanan harus disertai dengan pelayanan medis dengan cara pendampingan.

Tingkatan kedua yaitu keluarga membawa pasien berobat kerumah sakit dan keluarga sebagai penolong pertama bagi pasien dalam mencari bantuan/pertolongan kepada professional. Menurut teori (Keliat, 2010) keluarga merupakan faktor penting yang menentukan keberhasilan asuhan keperawatan pada pasien dengan halusinasi. Menurut artikel (Isti Harkomah, 2019) dan artikel (Sarah Parry \& Filippo Varese, 2021) Pengalaman keluarga merawat pasien skizofrenia dengan masalah halusinasi dengan cara membawa pasien kerumah sakit saat kambuh dan memberikan obat. Penyebab pasien kambuh biasanya stres dan tekanan batin. 


\section{Prosiding Seminar Nasional Kesehatan Lembaga Penelitian dan Pengabdian Masyarakat Universitas Muhammadiyah Pekajangan Pekalongan}

Pengalaman keluarga dalam merawat skizofrenia sangat berdampak sekali untuk kesembuhan pasien halusinasi. Beban yang dirasakan keluarga dipengaruhi oleh dukungan baik maka beban itu akan berkurang sehingga mengurangi beban keluarga dalam merawat (Byrne et al.., 2020).

Tingkatan ketiga yaitu keluarga mengajak pasien terlibat dalam kesiapan seharihari di rumah untuk mengontrol halusinasi dan keluarga berperan sebagai pendukung utama meningkatkan kemampuan. Menurut artikel (Isti Harkomah, 2019) salah satu faktor penyebab terjadinya halusinasi adalah tidak adanya komunikasi, komunikasi tertutup, tidak ada kehangatan dalam keluarga, faktor keturunan dan keluarga tidak tahu cara menangani perilaku pasien saat di rumah. Tindakan keluarga dalam merawat pasien seharusnya memberi obat secara teratur, sering mengajak komunikasi dan memberikan kegiatan di rumah seperti menyapu, membersihkan rumah dan mencuci piring.

Menurut artikel (Gajali, 2016) keluarga memonitor kemampuan dan kegiatan sehari-hari dengan cara keluarga merawat pasien dengan dilibatkan secara langsung dalam merawat pasien halusinasi. Keluarga diharapkan lebih mengerti, memahami dan mengetahui yang dapat berperan secara aktif sebagai pendukung utama bagi pasien yang juga akan meningkatkan kemampuan penyesuaian dirinya serta tidak rentan lagi terhadap pengaruh stresor psikososial. Upaya untuk meningkatkan pengetahuan pada keluarga pasien skizofrenia perlu diberikan penyuluhan dan pendidikan kesehatan, baik yang dilakukan secara langsung maupun tidak langsung.

\section{Kesimpulan}

Bagian kesimpulan Dari hasil pembahasan diatas dapat disimpulkan bahwa peran keluarga dibagi menjadi tiga tingkatan yaitu tingkatan pertama meliputi keluarga memberikan obat dan memastikan obat diminum oleh pasien secara teratur dan tepat waktu, keluarga membawa pasien berobat kerumah sakit, keluarga berperan sebagai pengambil keputusan pasien halusinasi, keluarga merawat pasien secara langsung, keluarga mencari informasi tentang diagnosis dan kondisi pasien serta cara perawatannya, keluarga sebagai pengambil keputusan dalam proses pengambilan keputusan, keluarga sebagai pemberi perawatan dalam pengetahuan. Tingkatan kedua meliputi keluarga membawa pasien berobat kerumah sakit dan keluarga sebagai penolong pertama bagi pasien dalam mencari bantuan/pertolongan kepada professional. Tingkatan ketiga meliputi keluarga mengajak pasien terlibat dalam kesiapan sehari-hari di rumah untuk mengontrol halusinasi dan keluarga berperan aktif sebagai pendukung utama meningkatkan kemampuan, keluarga memonitor kemampuan dan kegiatan pasien sehari-hari.

\section{Referensi}

[1] Byrne, RE, Reeve, S., Bird, JC, Jones, W., Shiers, D., Morrison, AP, Pyle, M.., \& Peters, S. (2020). Pandangan dokter tentang jenis pengobatan untuk psikosis episode pertama disampaikan dalam uji coba terkontrol secara acak.

[2] Elisabet Agnes Jaftoran, Budi Anna Keliat, EsYuliaWardani (2020). Nursing intervention, family's role, cadre's role and medical services: Case series on 


\section{Prosiding Seminar Nasional Kesehatan 2021 Lembaga Penelitian dan Pengabdian Masyarakat Universitas Muhammadiyah Pekajangan Pekalongan}

client with hallucination and self-care deficit.

[3] Gajali, \& Badar. (2016). Pengaruh family psychoeducation therapy terhadap kemampuan keluarga merawat pasien skizofrenia dengan halusinasi di kota Samarinda Kalimantan Timur. Jurnal Husada Mahakam, IV(3), 151-161

[4] Harkomah, I. (2019). Analisis Pengalaman Keluarga Merawat Pasien Skizofrenia dengan Masalah Halusinasi Pendengaran Pasca Hospitalisasi. Jurnal Endurance, 4(2), 282. https://doi.org/10.22216/jen.v4i2.3844

[5] Sarah Parry \& Filippo Varese. (2021). Listen to the parent... really listen to the child! Family narrative of supporting children hearing voices

[6] Susilawati, S., \& Fredrika, L. (2019). Pengaruh Intervensi Strategi Pelaksanaan Keluarga terhadap Pengetahuan dan Kemampuan Keluarga dalam Merawat Klien Skizofrenia dengan Halusinasi. Jurnal Keperawatan Silampari, 3(1), 405415. https://doi.org/10.31539/jks.v3i1.898

[7] Nasir, Abdul dan Abdul, Muhith, 2011. Dasar-dasar Keperawatan jiwa, Pengantar dan teori. Jakarta: Salemba Medika.

[8] Sarafino, E. P., \& Smith, T. W. (2014). Health Psychology Eight Edition. USA: John Wiley \& Sons, Inc

[9] Stuart., Gail, W. (2008). Buku Saku Keperawatan Jiwa. Edisi 5. Cetakan I. Jakarta : EGC 